INTERNATIONAL JOURNAL OF
ORGANIZATIONAL LEADERSHIP
www.AIMIJOURNAL.COM

\title{
Impact of Managerial Coaching on Organizational Citizenship Behavior: The Mediation and Moderation Model
}

\author{
Basharat $\operatorname{Raza}^{1^{*}}$, Muhammad Ali ${ }^{2}$, Samiah Ahmed ${ }^{1}$, Jamil Ahmad ${ }^{1}$ \\ ${ }^{1} \mathrm{PhD}$ Scholar, National College of Business Administration \& Economics, Lahore \\ ${ }^{2}$ Assistant Professor, Lahore Garrison, University, Lahore
}

\begin{tabular}{|c|c|}
\hline & ABstract \\
\hline \multicolumn{2}{|l|}{ Keywords: } \\
\hline $\begin{array}{l}\text { Managerial Coaching, } \\
\text { Thriving at Work, } \\
\text { Perception of } \\
\text { Organizational Politics, } \\
\text { Perceived Organizational } \\
\text { Support, OCB-I, and } \\
\text { OCB-O }\end{array}$ & $\begin{array}{l}\text { To fill the research gap of scarce literature and effectiveness of managerial coaching, this } \\
\text { study attempts to examine the influence of managerial coaching on employee organization } \\
\text { citizenship behavior through the mediating effect of thriving at work and moderating effect } \\
\text { of perception of organizational politics between managerial coaching and thriving at work. } \\
\text { Data was collected from the employees working in the pharmaceutical sector in Lahore, } \\
\text { Pakistan. By using structural equation modeling (SEM) analysis technique with } 361\end{array}$ \\
\hline $\begin{array}{l}\text { Received } \\
25 \text { September } 2017\end{array}$ & $\begin{array}{l}\text { workers' sample, results indicate that managerial coaching is positively correlated with } \\
\text { thriving at work, OCB-I and OCB-O and thriving at work mediate the relationship of }\end{array}$ \\
\hline $\begin{array}{l}\text { Received in revised form } \\
17 \text { February } 2018\end{array}$ & $\begin{array}{l}\text { managerial coaching and organizational citizenship behavior. The results also exhibit that } \\
\text { the relationship between managerial coaching and thriving at work is moderated by the }\end{array}$ \\
\hline $\begin{array}{l}\text { Accepted } \\
28 \text { February } 2018\end{array}$ & $\begin{array}{l}\text { perception of organizational politics. Furthermore, the practical implications of this study } \\
\text { are further discussed. }\end{array}$ \\
\hline
\end{tabular}

Correspondence:

basharat_hailians@hotmail.com

(C)AIMI Journals

Due to globalization and advancement of IT, the job environment is continuously changing in all over the world for the past few decades, and the nature of employmentenvironment is becoming more dynamic. Competitors are facing the new and vibrant markets. Now the organizations must put extra energies to maintain a sustainable competitive advantage to cope with challenging and complex business world (Delery \& Roumpi, 2017; Hagen, 2010; Pousa \& Mathieu, 2015). In this situation, the researchers and management emphasize on the enhancement of job performance skills for a better outcome (Pousa \& Mathieu, 2010; Pousa, 
Mathieu, \& Trepanier, 2017). The managerial coaching has become a popular practice for helping and training salespeople for boosting sales targets and results (Dahling, Taylor, Chau, \& Dwight, 2016; Deeter-Schmelz, Goebel, \& Kennedy, 2008; Pousa et al., 2017).

Coaching along with a set of activities has been considered necessary for achieving primary and secondary goals by the supervisors and HR development practitioners (Ellinger \& Kim, 2014; Woo, 2017). The theorists, trainers, and practitioners explore the impact and practical application of managerial coaching (Kim, Egan, Kim, \& Kim, 2013). Managerial coaching may be defined as an activemanagerial practice that helps and improves employee learning skills, behavior, and performance (Ellinger, Ellinger, Hamlin, \& Beattie, 2010). Managerial Coaching has been discussed as an authoritative technique for organization progress, structural transformation, employee training, learning and development, tactical management of human capital, and better functioning. It is also necessary for the succession planning and preparation of important posts in the governor and the performance management (Gilley, Gilley, \& Kouider, 2010; Jaques, 2017). In spite of increasing attention and related practice-oriented actions which emphasize the significance of the manager acting as coach, research on managerial coaching is scant (Beattie et al., 2014). There is a scarcity of empirical studies for the efficacy of managerial coaching (Agarwal, Angst, \& Magni, 2009). There are few outcome variables of managerial coaching effectiveness which has been explored in previous studies (Hagen, 2010; Kim et al., 2013). Following this, job performance is the key outcome variable of managerial coaching (Kim \& Kuo, 2015). As such, among the common outcome variables of managerial coaching, job performance is the more significant variable as the efficacy of managerial coaching can be realized in term of employee's in role performing (Ellinger, Ellinger, \& Keller, 2003; Huang \& Hsieh, 2015; Peterson \& Hicks, 1996).

Managerial coaching is delivered by the manager or executive to the junior or subordinate and top managers play a decisive role as a coach, and it can be suggested as a vital managerial act that enhances the employee efficiency, effectiveness, contribution, and learning (Ellinger et al., 2010; Park, 2007; Peterson \& Hicks, 1996; Ratiu, David, \& Baban, 2017). Moreover, concentrating on the organizational transformation and learning in the workplace, it is evident that the organizations are now transforming tasks typically related to HRD (Jones, Woods, \& Guillaume, 2016; Liu \& Batt, 2010). The changing of the job function has revolutionized the roles, responsibilities, and authorities of the managers and the organization's leaders. The ways of direction, control, and leading have been modified for achieving organizational strategic (long term) goals. This has given new direction to evaluating recognizing human resources and hence human capital (Ellinger et al., 2003; Muhlberger, \& Traut-Mattausch, 2015). All these ties desired outcomes and responsibilities are managed with the support of managerial coaching activities (Kim et al., 2013; Turner \& McCarthy, 2015).Consequently, to support the development of workforces, managers are required to act like educators (Cohen \& Tichy, 1998), coaches (McGill \& Slocum, 1999) and thrivers (Abid, 2013).

When subordinates and juniors recognize as a favor, then they feel more affiliation with their supervisor and they response results in job commitment, responsibility, and satisfaction (Sonenshein, Dutton, Grant, Spreitzer, \& Sutcliffe, 2013; Woo, 2017). In coaching environment, managers can increase the performance of their subordinates by providing clear goals and available resources (Kim, Egan, \& Moon, 2014). So, it is considered as a favor by 
manager and organization support for their subordinates (Kim, 2010); in return, employees perform extraordinary like organizational citizenship behavior toward the organization (Boyatzis, Smith, \& Beveridge, 2012; Kottke \& Sharafinski, 1988). Managerial coaching negatively related to turnover intentions rate (Kim, Eom, Kim, \& Youn, 2015), and positively related to OCB (Kim \& Kuo, 2015). When a manager acts as a role model, provide clear pathways, quick feedback, goals, and develop learning opportunities, then employees will feel learning and perform in-role and extra-role toward the organization (Colquitt, Scott, \& LePine, 2007; Ellinger et al., 2010) energetically.

Thriving at work can be increased through managerial coaching, to do so, we discussthriving at work. Moreover, the conception of "thriving at work" is currently attaining the attention in the workplace actions, movements, and positive organizational learning (Abid, 2013). Spreitzer, Sutcliffe, Dutton, Sonenshein, and Grant (2005) describes thriving at work with the combination of learning and vitality. Elliott and Dweck (1988) discuss and elaborate that learning element of thriving is featured by achievement and application of new sciences and knowledge and vitality means the positive feelings and having the vigor and enthusiasm (Nix, Ryan, Manly, \& Deci, 1999). Moreover, learning and vitality have been investigated independently, yet modern research focused on learning and vitality jointly, which called thriving at work (Porath, Spreitzer, Gibson \& Garnett, 2012). Hence, both of the psychological conditions are together in the workplace setting related to the encouraging consequences for the employees as well as their organizations (Spreitzer, Porath, \& Gibson, 2012). Further, Abid and Ahmed (2016) describe thriving at work in three dimensions, namely cognitive, affective, and behavioral element. Employees behave creatively and show the favorable attitudes when they feel thrive in their workplace as a result of managerial coaching (Sonenshein et al., 2013). When manager provides clear pathways, quick feedback, and goals and develops learning opportunities, then employees do innovative actions. Previous literature found that thriving employees are committed to their organization, take less sick leaves, seek out opportunities for learning and grow and behave positively (Lambert, Vero, \& Zimmermann 2012; Spreitzer et al., 2012). Employees thrive at work support and help their colleagues and encourage affiliation (Spreitzer \& Porath 2014). Nowadays, in a dynamic work environment, customers demand randomness; so, it is mandatory for employees to perform extra performance to satisfy customer needs. Therefore, it is required at this time to explore the outcomes of managerial coaching activities like OCB and creative actions of employees (Oh \& Tak, 2016). So, this study will fill this research gap by providing empirical support for managerial coaching activities and their outcomes.

According to the related literature review indicating that perception of organizational politics will moderate the relationship of managerial coaching and thriving at work, we discuss the role of perception of organizational politics. Organizational politics denote self-interested activities which are not supported by the organization, and the consequences of these behaviors are detrimental for their employees and organization (Ferris \& Kacmar, 1992). Perception of the organizational politics (POP) is the magnitude to whom workers perceive political actions as prevalent in their tasks. POP harms the productivity and performance of employees at the individual and organizational level because it affects the usual procedures of organizations like promotions, reward, and decision making (Dhar, 2009). It can increase or decrease the degree 
of satisfaction of employees because it is strongly connected with fairness and justice (Saleem, 2015). By expectancy theory and social exchange theory (Blau, 1964), if an organization wants to succeed, then it is necessary to create a fair and balanced relationship between managers and employees (Gadot, 2007). Leader or coach is an important factor, which can change the perception of organizational politics (Kacmar \& Baron, 1999), and further, affect the satisfaction level of employees about their effort. It is the duty of a leader to create a healthy and fair environment in the organization and manage POP of the workers that enhance their outcomes (Ram \& Prabhakr, 2010). A competent manager who has coached abilities can minimize or moderate the POP effect, which further increase is thriving at work and job performance (OCB-I and OCB-O). The outcomes of organizational politics are both negative and positive, but negative or harmful results are more prominent and these adverse outcomes enhance work stress, lower job performance, less organizational commitment, and decrease satisfaction level (Kacmar \& Baron, 1999; Vigoda, 2002), reduced individual and organizational performance and reduced organizational citizenship behaviors (Vigoda, 2000), increase withdrawal behaviors (Poon, 2003; Valle \& Perrewe, 2000). By developing a fair and justice, environment might increase thriving at work and job performance (OCB-I and OCB$\mathrm{O})$.

POP has an adverse effect on employee outcomes like job satisfaction and affective organizational commitment (Butt, Imran, Shah \& Jabbar, 2013). In politically oriented organizations, distribution of rewards is based on favoritism not on merit system (Rusbult, Campbell \& Price, 1990). POP creates a stressful environment and has an adverse effect on job attitudes and performance (Ferris, Russ, \& Fandt, 1989). In a politicalclimate, employees perceive that their employer does not treat them equally which distorts the employment relationship with the organization or supervisors, which eventually diminishes the employee performance (Chang, Rosen, \& Levy, 2009) and aggravates negative outcome like withdrawal behavior, absenteeism, low job performance, and job worry arise (Ferris \& Kacmar, 1992). To sum up, we can say that perceptions of organizational politics may moderate the relationship of managerial coaching and employees' thriving at work.

Thriving at work and job performance (OCB-I and OCB-O) are important outcomes of managerial coaching which have been continuously recognized. Another significant research gap in the literature on managerial coaching is an investigation of its practices and effectiveness outside the Western countries (Beattie et al., 2014). So, the objective of the current research is to examine the relationship among the managerial coaching, thriving at work, OCB-I, and OCB-O with the mediating effect of thriving at work as well as the moderating role of POP between managerial coaching and thriving at work.

\section{Managerial Coaching and OCB}

Managerial coaching is "a method of facilitator of learning which is provided by a supervisor or manager enabling the employees to learn and enhance the performance" (Ellinger et al., 2010). It is considered a tool for developing the performance of subordinates (Grant, 2006; Jones et al., 2016). Coaching is different and updated from the old management because it contains self-directed, allowing, cooperation and team work strategies instead of a reliance on the steering, monitoring, and strictly where it is prepended an increasing collaboration in the 
workplace setting (Boyatzis et al., 2012; Muhlberger \& Traut-Mattausch, 2015). Moreover, in the managerial coaching, considering a rapid feedback, training, and guiding (Kim et al., 2013), giving sound tracks of goals, performing as a role model, creating learning opportunities at work, and refining the prospects of attainment and progress of employees (Kim et al., 2014; Ratiu et al., 2017) are important.

Employees can perform extra-role performance regarding technical behaviors like psychological and societal (Motowidlo \& Van Scotter, 1994). An extra-role performance is described as a cooperative and social action by Van Dyne, Cummings, and Parks (1995), which grows work associations. More importantly, Organ, Podsakoff, and MacKenzie (2005) described extra-role activities that are the kinds of organizational citizenship behavior, which employees perform beyond their formal duties. There are two types of organizational citizenship behavior including OCBO and OCBI which are described in the literature. OCBO is attached to the organizationbecause it is valuable to the organization and OCBI is connected to an individual because it is directly relevant to employees and indirectly valuable to the organization (Williams \& Anderson, 1991).

Coaching thought by employees as an organization support (Kim, 2014) and management support (Boyatzis et al., 2012) are described in social exchange theory. Coaching considered an investment to their employees in term of effective leadership, attention, precisely goals and pathways, quick response and personalized training and supervision, which in turn enhance employees' organization citizenship behavior (Bester, Stander, \& Van, 2015; Kottke \& Sharafinski, 1988; Podsakoff, MacKenzie, Moorman, \& Fetter, 1990). Furthermore, managerial coaching directly associated with organizational citizenship behavior (Dekas, Bauer, Welle, Kurkoski, \& Sullivan, 2013; Ellinger \& Cseh, 2007).

\section{Mediating Role of Thriving at Work}

Many researchers mark managerial coaching association with active listening skills, questioning skills, logical skills, thought, quick response, openness of ideas, numerous views in decision making, cognitive or intellectual, open communication, explanation of goals and approaches, cooperation, teamwork, and forming a supportive atmosphere (Cox, Bachkirova \& Clutterbuck, 2010; Jones et al., 2016).The managers who desire to form the stable and beneficial relationships for the benefit of their subordinates, they must accept help activities appreciating the effort of their employees (Zhang, Tsui, Song, Li, \& Jia, 2008) which in turn creates healthy environments (May, Gilson, \& Harter, 2004) and considered friendliness by employees. In this situation, employees are self-confident to accept dangers and threats, because they assure that they will be backed by their manager (Abid, Zahra, \& Ahmed, 2015; Kahn, 1990) and consider perceived organizational support by their organization (Zagenczyk, Scott, Gibney, Murrell, \& Thatcher, 2010). When employees see support by their organization, then they increase enthusiasm for creativity and new knowledge. Thus, healthy and supportive environment enhances thriving at work (Wiesenfeld, Raghuram, \& Garud, 2001) which in return employee performs a constructive attitude (Kwon, 2015) encouraging opinions (Yang et al., 2015) towards their determination and obligations. Therefore, in coaching activities manager provides fast feedback for improving performance, and subordinate feels the 
responsibility to answer the manager by developing the satisfactory attitudes and thriving at work (Huang \& Hsieh, 2015; Sonenshein et al., 2013).

The perceived organizational support theory discusses the link between managerial coaching activities, thriving at work and job performance, and it elaborates the exchange between the organization and employee (Eisenberger, Fasolo, \& Davis-LaMastro, 1990). Employee conceives organizational reward as psychological satisfaction, resultantly he performs his duties and obligations successfully (Abid et al., 2015). Kottke and Sharafinski (1988) proved that leaders and employees' relationships are so important that employees might distinguish their leader and manager's positive positioning for them as a demonstration of organizational backing.

In the coaching atmosphere, the managers do the role as an instructor and subordinates identify their natural processes as good will. Managers accomplish different activities as providing clear purposes and means, provide prompt feedback for performance enhancement (Jones et al., 2016; Kim, 2014). When subordinates perceive supportive behavior as coaching affiliation with the manager, subordinate feels the responsibility to answer by improving the favorable attitudes and thriving at work (Sonenshein et al., 2013). Hence, the theoretical model advanced by Spreitzer et al.(2005) recommends that when individuals thrive at work, then they cautiously communicate with other subordinates, improve interpersonal skills, and take consideration of the others' needs at the workplace. Therefore, furthering the arguments, organizational support theory explains the exchange relationship between employee and organization, and actions performed by a manager or leader are perceived as the spokesperson of the organization. When employees view the favorable actions from their manager or supervisor, organizational support enables them to improve their work.

Supervisors should value the work and adopt helping behavior to their subordinates for welfare and strong relationships with their employees (Zhang et al., 2008). Consequently these helping behavior build productive and healthy environment for employees (May et al., 2004). In such healthy and learning environment, employees work creatively and do risky tasks for the enhancement of organizational performance, because they assume that they are supported and backed by management and organization (Abid et al., 2015). To this end, employees feel confident as they are backed by an organization (Zagenczyk et al., 2010). This kind of supportive behavior by organizations improves the knowledge and creativity of employees. Hence, caring, learning, and supportive environment increase thriving at work (Wiesenfeld et al., 2001). Moreover, in coaching behavior, a manager creates learning opportunities and give clear pathways and goals, which improve the in-role and extra-role behavior of employees for the improvement of organization (Colquitt et al., 2007).

Employees improve their performance when they thrive in their work setting (Abid, 2013; Porath et al., 2012). In one university research, this relationship is also supported; being great thrived employees have higher levels of performance (Porath et al., 2012). Employees who are thriving in their work setting, they are more initiative and find out more opportunities as compared to less thriving employees (Porath et al., 2012).

Similarly, these relationships are consistent with the executive literature, as thrived executives are more active and initiative as compared to less thriving executive (Porath et al., 2012). Employees considered as a role model for these thrived leaders. Thrived coaches 
empower their subordinate to think creatively and feel thriving at work. Prosper employees take care of their colleague and build helping and learning environment (Abid et al., 2015; Spreitzer et al., 2005) and perform organizational citizenship behaviors.

So, the mechanism of the relationships of managerial coaching and organizational outcome understood with the help of the mediating role of thriving at work. Therefore, in this research study thriving at work tries to enhance the employees' capabilities and skills wholly. Consequently, employees build positive views (Yang et al., 2015) and perform positive attitude (Kwon, 2015) for attaining organizational goals. Consequently, thrive employees enhance organizational citizenship behavior (OCB-I and OCB-O). So, it can be proposed that managerial coaching is associated with thriving at work, and further, thriving at work, mediate the relationship of managerial coaching and OCB-I \& OCB-O.

\section{Moderating Role of POP}

POP is a personal viewpoint and self-serving behavior about the environment, which is observed by an employee in a workplace. By self-determination theory, employees feel proficiency, independence, and understanding when they are intrinsically motivated (Deci \& Ryan, 1985); but in a political environment decisions are taken by some authorized persons and power is given to their favorite person, then in this situation employees reduce their intrinsic motivation, proficiency, performance, and consequently feel an imbalance (Ryan \& Deci, 2000). Furthermore, it triggers increased turnover intentions, counterproductive and withdrawal behaviors, and absenteeism, which is detrimental for organizations (Rodell \& Judge, 2009). Previous research has explored that in political environment employees' job satisfaction, commitment, and accelerating job stress decrease (Atinc, Darrat, Fuller, \& Parker, 2010). Manager improves the performance of employees by creating a learning environment in the organization (Colquitt et al., 2007). Thrived employees take creativity at their work place for the improvement of performance (Porath et al., 2012).

Employees see a threat when they perceive high organizational politics in their work environment. In these circumstances, employees often lose the confidence and support (Erkutlu \& Chafra, 2015). By the social exchange viewpoint, in a political environment, employees feel a lack of transparency, ambiguity, and uncertainty about the organizational reward system (Hall, Hochwarter, Ferris, \& Bowen, 2004). So, POP will moderate the relationship of managerial coaching and thriving at work. Thus, we can say that POP moderates or weakens the positive correlation of managerial coaching and thriving at work.

Therefore, grounded in the theory of organizational support, our theoretical model contains managerial coaching eventually influencing thriving at work, which further enhances organizational citizenship behavior with the prerequisite of the moderating effect of perception of organizational politics. 


\section{The Study}

The conceptual framework of the study is presented in Figure 1.

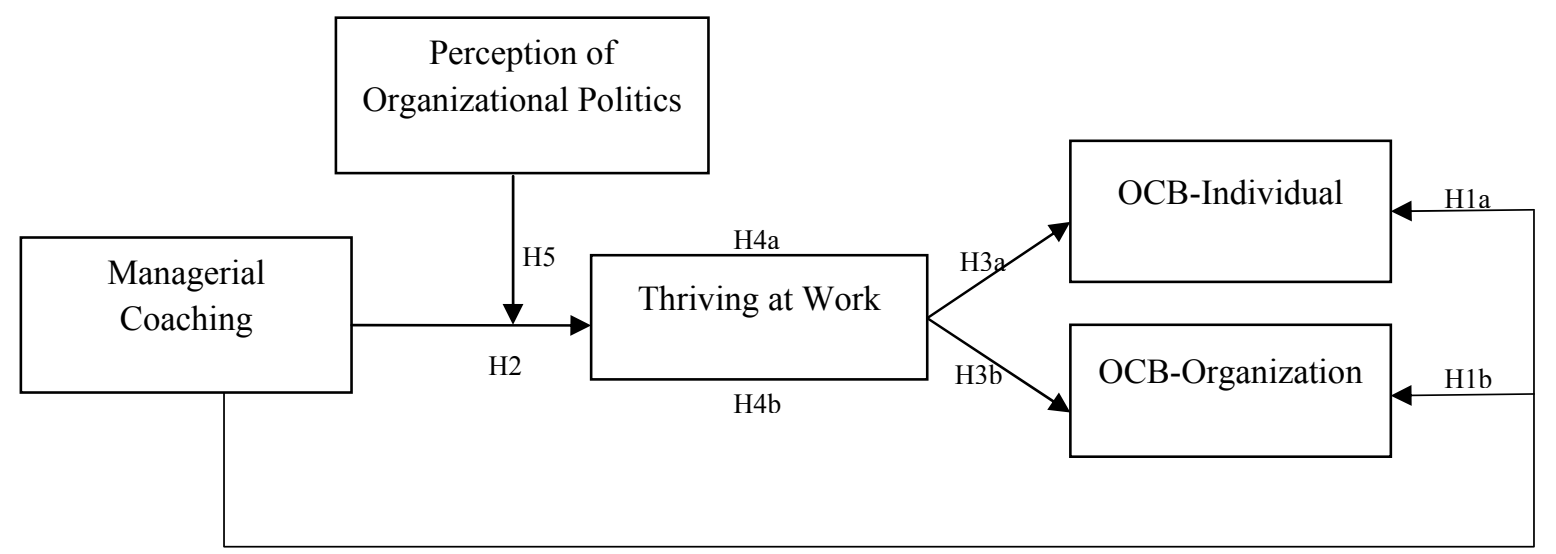

Figure 1. Mechanism of the relationship of managerial coaching with OCB-I and OCB-O.

\section{Research Questions and Research Hypotheses}

This study determines the results of the following research questions:

- What is the relationship between the managerial coaching conduct of a supervisor with thriving at work, OCB-I, and OCB-O?

- Does thriving at work mediate the relationship of managerial coaching and job Performance (OCB-I and OCB-O)?

- Does the association between managerial coaching and thriving at work is moderated by the POP?

The following research hypotheses guided the study:

$\mathbf{H}_{1 \mathbf{a}}$ : Managerial coaching will have a positive impact on employee OCBI.

$\mathbf{H}_{\mathbf{1 b}}$ : Managerial coaching will have a positive impact on employee OCBO.

$\mathbf{H}_{2}$ : Managerial coaching is positively related to employee thriving at work.

$\mathbf{H}_{3 \mathbf{a}}$ : Thriving at work will have a positive impact on employee OCB-me.

$\mathbf{H}_{3 \mathbf{b}}$ : Thriving at work will have a positive impact on employee OCB-O.

$\mathbf{H}_{\mathbf{4}}$ : Thriving at work will mediate the relationship of managerial coaching and OCB-I.

$\mathbf{H}_{\mathbf{4}}$ : Thriving at work will mediate the relationship of managerial coaching and OCB-O.

$\mathbf{H}_{5}$ : POP will moderate the relationship of managerial coaching and thriving at work.

\section{Method}

This segment discusses the data collection procedure, study sample, measurement of variables, and data analysis strategy.

\section{Sample and Procedure}

The respondents in this study were full-time workers of the pharmaceutical sector of Lahore in Pakistan. This model applies to the pharmaceutical industry because this sector adopts such motivational managerial services to enhance their sales and market share through their workforce. Managers or employees of this industry may behave politically for gaining and 
speedily career development. Firstly, we contacted human resource managers of various pharmaceutical companies, which helped us organize a randomly selected list of 480 pharmaceutical employees. With acquisition support of the superior body of the organization in the participating companies, we adopted a questionnaire to gather the facts from respondents. Structured questionnaires were utilized to collect cross sectional data from them and were translated from English into Urdu for the better understanding of the respondents (Brislin, 1980). Questionnaires were directly sent to sales representatives with permission of their organization head in sealed envelopes. The sample of the present study consisted of 361 (response rate approximately $75.2 \%$ ) respondents through simple random technique. This technique was used for the generalizability of the survey and for avoiding bias.

In this study, $83.9 \%$ were male, and $16.1 \%$ were females, $59.8 \%$ were in the 26 to 30 age bracket, $60.9 \%$ had a master's education, and $56.3 \%$ had 1 to 5 years of job experience.

\section{Measures}

\section{Managerial Coaching}

Coaching was measured with 11 items, which was developed by Park (2007). The sample item is: "To improve workplace performance, my manager constantly provides feedback". The scale ranges from 1 (strongly disagree) to 5 (strongly agree).

\section{Thriving at Work}

Thriving was measured with 10 items, which was developed by Porath, Spreitzer, Gibson, and Garnett, (2012). The sample item is "I find myself learning often" and "I feel alive and vital."The scale ranges, too $(1=$ strongly disagree to $5=$ strongly agree $)$.

\section{Organizational Citizenship Behavior-Individual}

OCBI was measured with three items, which was developed by Williams and Anderson (1991). The sample item is "This employee goes out of his/her way to help new employees." The scale ranges from 1 (never) to 5 (always).

\section{Organizational Citizenship Behavior-Organization}

OCBO was measured with three items, which was developed by Williams and Anderson (1991). The sample item is "This employee conserves and protects organizational property." The scale ranges from 1 (never) to 5 (always).

\section{Perception of Organizational Politics}

The15-item scale was used to assess the respondent's views regarding POP Scale by Kacmar and Carlson's (1997). An example item is "Promotions around here are not valued much because how they are determined is so political." Respondents were asked to rate their POP experience during their work from scale range $(1=$ strongly disagree to $5=$ strongly agree $)$.

\section{Common Method Variance}

A common method variance may be an issue in this study because data is collected through self-reporting measures of managerial coaching, thriving at work, OCB, and POP. Harman's 
single factor test is used to identify the common method bias (Podsakoff, MacKenzie, Lee, \& Podsakoff, 2003). The common method variance is not an issue in this research because single factor showed only $25 \%$ of the total variance. By Harman's test, "if one factor explains more than $50 \%$ of the variance in the items, methods bias is present" (Mattila \& Enz, 2002).

\section{Results}

\section{Analysis Strategy}

Data analysis is carried out through Statistical Packages for Social Sciences (SPSS version 22) and its extension Amos with Structural Equation Model technique. The analysisis alienated into descriptive statistics, assessment of the measurement model, reliability using Cronbach's alpha, convergent validity via average variance extracted (AVE), and discriminant validity using Fornell-Larcker criterion, confirmatory factor analysis, hypothesis testing, mediation, and moderation analysis were confirmed.

Table 1 represents the means and standard deviations.

Table 1

Means and Standard Deviations

\begin{tabular}{lcc}
\hline & Mean & STD. Deviation \\
\hline Managerial Coaching & 3.72 & 0.53 \\
Thriving at Work & 3.76 & 0.36 \\
OCB-Individual & 3.70 & 0.49 \\
OCB-Organization & 3.84 & 0.72 \\
POP & 3.44 & 0.63 \\
\hline
\end{tabular}

Table 1 describesthat managerial coaching, thriving at work, OCB-I, OCB-O, and POP are perceived in their work setting, because all mean values are greater than 3 .

\section{Confirmatory Factor Analysis}

For assessing validity, confirmatory factor analysis should be conducted. Measurement model should be evaluatedbefore carrying out confirmatory factor analysis (Anderson \& Gerbing, 1988). Therefore, in this study measurement model is evaluatedbefore confirmatory factor analysis.

\section{Measurement Model}

Through fit indices, measurement model has been assessed. In the results, fit indices values have shown a good fit $\left(\chi 2=1647.57, \mathrm{df}=798, \chi^{2} / \mathrm{df}=2.06, \mathrm{RMSEA}=0.07, \mathrm{CFI}=0.92\right.$, $\mathrm{NNFI}=0.91)$, as these values are better suggested cut-off $(\chi 2 / \mathrm{df}<3$, RMSEA $<0.08, \mathrm{CFI}>0.95$, NNFI>0.95) (Bagozzi \& Yi, 1988; Browne \& Cudeck, 1993; Hu \& Bentler, 1999). The value of CFI and NNFI equal to 0.90 also was acceptable as suggested by Cheung and Rensvold (2002).

Table 2 shows the results of construct reliability and convergent validity of constructs. 
Table 2

Results of Construct Reliability and Convergent Validity of Constructs

\begin{tabular}{lccc}
\hline Factor & Composite Reliability CR $>0.7$ & Average variance Extracted (AVE) $\geq 0.5$ & Square root AVE \\
\hline Managerial Coaching & 0.85 & 0.60 & 0.77 \\
Thriving at Work & 0.80 & 0.56 & 0.75 \\
OCB-Individual & 0.84 & 0.68 & 0.82 \\
OCB-Organization & 0.89 & 0.63 & 0.79 \\
POP & 0.91 & 0.58 & 0.76 \\
\hline
\end{tabular}

Reliability was checkedthrough the Cronbach's alpha method. Cronbach alpha values are presented in Table 2. The data is reliable for further analysis because Cronbach's alpha of all variables exceeds $(>0.70)$ (Kline, 2005).

Convergent and discriminant validity were performed to assess constructvalidity and this study provides initial validation for these validities. The values of AVE are shown in Table 3, which is greater than 0.5 (AVE $\geq 0.5$ ), and Cronbach's alpha values are higher than 0.70 , so the convergent validity seems to be achieved (Fornell \& Larcker, 1981; Hair, Anderson, Tatham, \& Black, 1995).

Table 3 exhibits the results of discriminant validity.

Table 3

Results of Discriminant Validity

\begin{tabular}{|c|c|c|c|c|c|c|c|}
\hline \multicolumn{8}{|c|}{ Correlations } \\
\hline & 1 & 2 & 3 & 4 & 5 & $\mathrm{CR}$ & AVE \\
\hline 1. Managerial Coaching & 0.77 & & & & & 0.85 & 0.60 \\
\hline 2. Thriving at Work & $0.28^{* *}$ & 0.75 & & & & 0.80 & 0.56 \\
\hline 3. OCB-Individual & $0.35^{* *}$ & $0.48^{* *}$ & 0.82 & & & 0.84 & 0.68 \\
\hline 4. OCB-Organization & $0.38^{* *}$ & $0.50^{* *}$ & $0.31^{* *}$ & 0.79 & & 0.89 & 0.63 \\
\hline 5. POP & $-.33^{* *}$ & $-.50^{* *}$ & -.13 & -.15 & 0.76 & 0.91 & 0.58 \\
\hline
\end{tabular}

** Correlation is significant at the 0.01 level (2-tailed).

In this study it is aimed to check out discriminant validity through Fornell-Larcker criterion, in which square root of AVE and inter-construct correlation values are compared. For discriminant validity, the values of the square root of AVE should be greater than the correlation of the variable (Kim, 2010). The values of the square root of AVE are higher than the correlation of variables, which are shown in Table 3.

Managerial coaching was positively correlated with thriving at work $(r=0.28, p<.01)$, OCB-I $(r=0.35, p<0.01)$, OCB-O $(r=0.38, p<0.01)$, and negatively correlated with POP $(r=0.33, p<0.01)$. Moreover, thriving at work positively correlated with OCB-I $(r=0.48, p$ $<.01)$, and OCB-O $(r=0.50, p<.01)$. Furthermore, POP was negatively correlated with thriving at work $(r=0.50, p<0.01)$. These results are consistent with hypotheses and provide initial support for our hypotheses. Correlation coefficients were lower $(<0.70)$ (Tabachnick \& Fidell, 1996), so multicollinearity does not issue in the study.

\section{Hypotheses Testing}

Hypotheses are analyzed through structural model. In the results, fit indices values have shown a good fit $\left(\chi^{2}=1045.52, \mathrm{df}=350, \chi^{2} / \mathrm{df}=2.98, \mathrm{RMSEA}=0.05, \mathrm{CFI}=0.95, \mathrm{NNFI}=0.90\right)$, as 
these values are better suggested cut-off $\left(\chi^{2} / \mathrm{df}<3\right.$, RMSEA $<0.08$, CFI $>0.95$, NNFI $\left.>0.95\right)$ (Bagozzi \& Yi, 1988; Browne \& Cudeck,1993; and Hu \& Bentler, 1999).

Table 4 represents the results of structural model.

Table 4

Results of Structural Model

\begin{tabular}{|c|c|c|c|c|c|c|c|}
\hline Hypotheses & & thes & ed Paths & $\begin{array}{c}\text { Standardized Regression } \\
\text { Weights }(\beta)\end{array}$ & t-value & P-value & Results \\
\hline $\mathrm{H}_{1 \mathrm{a}}$ & OCB-Individual & $\leftarrow$ & Managerial Coaching & 0.50 & 15.87 & 0.00 & Accepted \\
\hline $\mathrm{H}_{1 \mathrm{~b}}$ & OCB-Organization & $\leftarrow$ & Managerial Coaching & 0.44 & 10.31 & $* * *$ & Accepted \\
\hline $\mathrm{H}_{2}$ & Thriving at Work & $\leftarrow$ & Managerial Coaching & 0.38 & 7.79 & $* * *$ & Accepted \\
\hline $\mathrm{H}_{3 \mathrm{a}}$ & OCB-Individual & $\leftarrow$ & Thriving at Work & 0.32 & 7.50 & $* * *$ & Accepted \\
\hline $\mathrm{H}_{3 \mathrm{~b}}$ & OCB-Organization & $\leftarrow$ & Thriving at Work & 0.48 & 11.58 & $* * *$ & Accepted \\
\hline
\end{tabular}

Significant at $\mathrm{p}<0.001 ; * *$ significant at $\mathrm{p}<0.01 ; *$ significant at $\mathrm{p}<0.05$

The analysis identifies that all hypotheses have got the support from statistics. $\mathrm{H}_{1 \mathrm{a}}$ posits that managerial coaching has positive impact on OCB-Individual and it is supported with $\beta=$ $0.50, \mathrm{p}<0.00 . \mathrm{H}_{1 \mathrm{~b}}$ asserts that managerial coaching has positive impact on OCB-Organization and it is supported with $\beta=0.44, \mathrm{p}<0.00 . \mathrm{H}_{2}$ proposes that managerial coaching has positive impact on thriving at work and it is supported with $\beta=0.38, \mathrm{p}<0.00 . \mathrm{H}_{3 \mathrm{a}}$ posits that thriving at work has positive impact on OCB-Individual and it is supported with $\beta=0.32, p<0.001$. Moreover, $\mathrm{H}_{3 \mathrm{~b}}$ asserts that thriving at work has positive impact on OCB-Organization and it is supported with $\beta=0.48, \mathrm{p}<0.00$.

\section{Role of Thriving at Work as Mediator}

Two structural models have been tested for mediation analysis with a direct path from managerial coaching to OCB and indirect paths via thriving at work as suggested by Iacobucci, Saldanha, and Deng (2007).

\section{Mediation Model 1}

There is a good fit model as shown in the structural model $\left(\chi^{2}=1048, \mathrm{df}=431, \chi 2 / \mathrm{df}=2.43\right.$, $\mathrm{RMSEA}=0.06, \mathrm{NNFI}=0.90, \mathrm{CFI}=0.96$ ).

Table 5 exhibits the direct and indirect path coefficients of mediation model 1.

Table 5

Direct and Indirect Path Coefficients of Mediation Model 1

\begin{tabular}{lccc}
\hline Predictor & Direct Effects & Indirect Effects via Thriving at Work & Total Effects \\
\hline Managerial Coaching & 0.50 (significant) at $\mathrm{p}>0.05$ & 0.07 (significant) at $\mathrm{p}<0.05$ & 0.57 \\
\hline
\end{tabular}

Table 5 shows that the path coefficient for the direct effect of managerial coaching on OCBIndividual is significant. Managerial coaching has a significant impact on OCB-I through an indirect effect via thriving at work. Therefore, we can say that thriving at work partial mediates the relationship between managerial coaching and OCB-I, supported $\mathrm{H}_{4 a}$. 


\section{Mediation Model 2}

There is a good fit model as presented in the structural model $\left(\chi^{2}=1044\right.$, $\mathrm{df}=353, \chi^{2} / \mathrm{df}=$ 2.95, $\mathrm{RMSEA}=0.04, \mathrm{NNFI}=0.95, \mathrm{CFI}=0.96$ ).

Table 6 shows the direct and indirect path coefficients of mediation model 2.

Table 6

Direct and Indirect Path Coefficients of Mediation Model 2

\begin{tabular}{lccc}
\hline Predictor & Direct Effects & Indirect Effects via Work Family Balance & Total Effects \\
\hline Managerial Coaching & 0.44 (significant) at $\mathrm{p}>0.05$ & 0.20 (significant) at $\mathrm{p}<0.05$ & 0.64 \\
\hline
\end{tabular}

According to Table 6, the path coefficient for the direct effect of managerial coaching on OCB-Organization is significant. Managerial coaching has a significant impact on the OCB Organization through an indirect effect via thriving at work. Therefore, it can be stated that thriving at work partial mediates the relationship between managerial coaching and OCBOrganization, supported $\mathrm{H}_{4 \mathrm{~b}}$.

\section{Moderating Role of Perception of Organizational Politics}

Baron and Kenny (1986) has been used to test the moderation. A structural model has been developed with interaction terms. There is a good fit model as presented in moderation model $\left(\chi 2=5.34, \mathrm{df}=2.2, \chi^{2} / \mathrm{df}=2.43, \mathrm{RMSEA}=0.06, \mathrm{NNFI}=0.97, \mathrm{CFI}=0.94\right)$.

Table 7 presents the results of moderation analysis.

Table 7

Results of Moderation Analysis

\begin{tabular}{|c|c|c|c|c|c|c|}
\hline Hypotheses & \multicolumn{2}{|c|}{ Hypothesized Paths } & $\begin{array}{c}\text { Standardized Regression } \\
\text { Weights }(\beta)\end{array}$ & T-Value & P-Value & Results \\
\hline \multirow{3}{*}{$\mathrm{H}_{4}$} & Z_Thriving at Work & Z_Managerial Coaching & 0.28 & 8.02 & $* * *$ & \multirow{3}{*}{ Accepted } \\
\hline & Z_Thriving at Work & Z_POP & -0.32 & -6.82 & $* * *$ & \\
\hline & Z_Thriving at Work & Interaction & -0.27 & -7.53 & $* * *$ & \\
\hline
\end{tabular}

*** Significant at $\mathrm{p}<0.001 ; * *$ significant at $\mathrm{p}<0.01 ; *$ significant at $\mathrm{p}<0.05$

$\mathrm{H}_{2}$ posits that perception of organizational politics moderates the relationship of managerial coaching and thriving at work. Following this if the POP is high, it will weaken the relationship of managerial coaching and thriving at work and vice versa, and it is supported. Table 7 shows that the standardized regression coefficients from the interaction term are -0.27 which is significant with $\mathrm{t}=-7.53, \mathrm{p}<0.00$.

The interaction moderation graph shows that POP dampens the positive relationship between managerial coaching and thriving at work. The study gets moderation support.

Figure 2 shows thriving at work. 


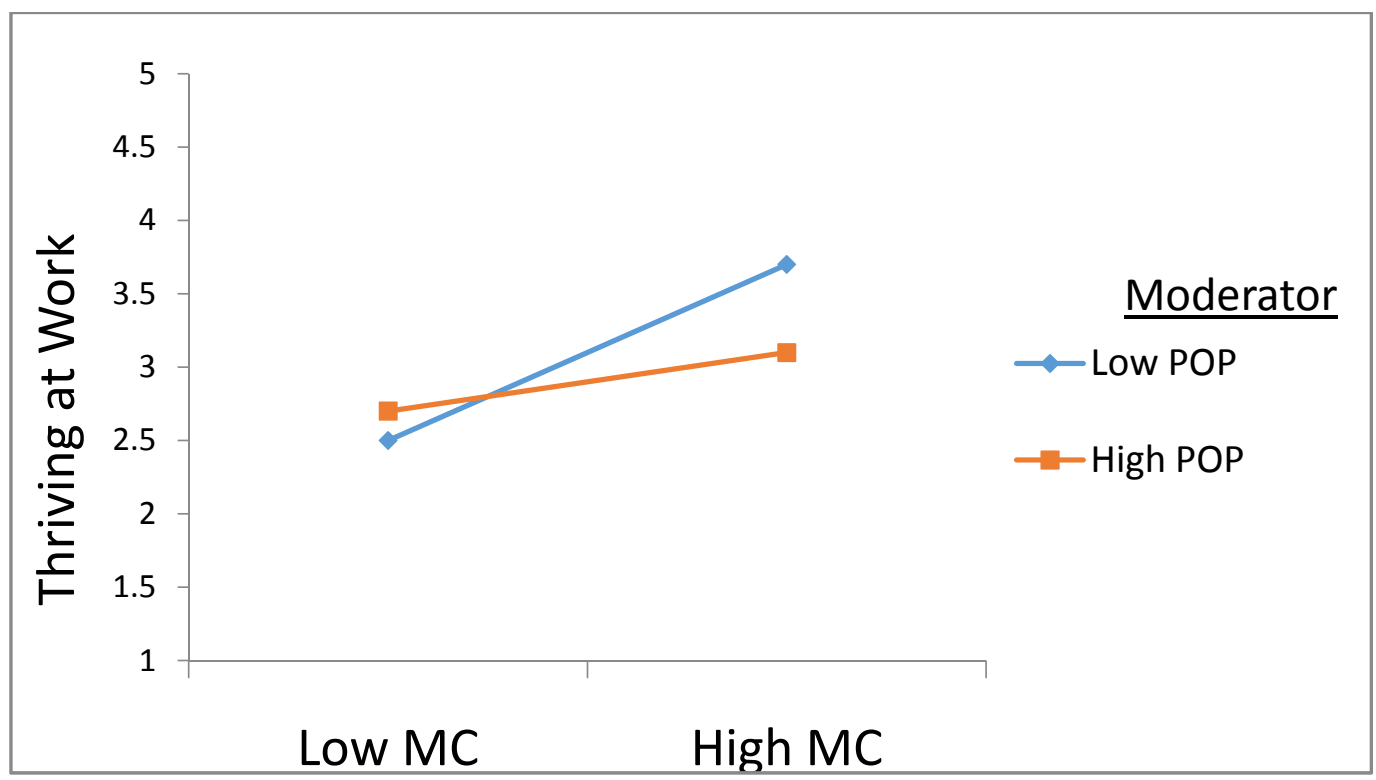

Figure 2. Thriving at Work

\section{Discussion and Conclusion}

The present study focused on the relationships of managerial coaching, worker thriving at work, OCB-I and OCB-O, mediating role of thriving at work, and moderating role of POP by employees using the 361 samples from full-time workers of the pharmaceutical sector. The study tested the hypotheses, which developed and was guided by social exchange theory. The results of structural equation modeling revealed that the empirical data supported hypotheses. The results showed that managerial coaching brings changes in OCB-I and OCB-O though, is mediating effect of thriving at work, and these findings are consistent with previous researchers (Organ et al., 2005). Kim and Kuo (2015) found out the relationships of managerial coaching and OCB-I and OCB-O through the trustworthiness. The analysis showed the relationship between managerial coaching and thriving at work is in line with findings of different researchers (Liang, \& Wang, 2016). Ye, Wang, Wendt, Wu, and Euwema (2016) found out that female managers exhibit more coaching as compared to male managers. POP had a moderating effect on the relationship of managerial coaching and thriving at work. The moderating role of POP between managerial coaching and employee thriving at work is also consistent with the findings (Butt et al., 2013).

Considering another study, Hahn (2016) found out that managerial coaching brings changes in OCB and innovative behavior, which means when an employee perceives coaching from the manger, then they perform better (Zemke, 1996) and resultantly think innovatively and come up with novel ideas (Hahn, 2016). Managerial coaching positively associated with employee thriving at work. Employees felt confident and supported in a coaching environment resultantly accept risks for the advancement of the organization (Kahn, 1990). When a manager acts as a coach, it is considered a goodwill of the manager by subordinates. The manager provides fast response for improving performance, makes opportunities for learning and improves prospects for the achievement and betterment of personnel in a coaching environment (Kim et al., 2014). 
POP moderated or weakened the relationship of managerial coaching and thriving at work. In a politicalenvironment, where decisions are taken by some authorized persons and power distributed to their favorite person, employees reduced their intrinsic motivation and consequently feeling the imbalance, they reduced their proficiency and performance (Ryan \& Deci, 2000). So, employees thriving at work will be decreased. Employees who received coaching from their direct managers, they will feel learning and positive feelings and have the vigor and enthusiasm; but POP will change these learning and positive feelings in negative views about the manager and the organization (Lau, Tong, Lien, Hsu, \& Chong, 2017), which modifies the relationship of managerial coaching and thriving at work.

We found the relationship of managerial coaching on employee thriving at work and employee outcomes (OCB-I and OCB-O) as well as mediating role of thriving at work and moderating role of POP between the relationship of managerial coaching and thriving at work. The results supported the hypotheses, which was empirically tested in this study. For enhancing thriving at work and employee outcomes, the manager should provide fast response for improving performance, make opportunities for learning, and improve prospects for achievement.

The current study describes some limitations which can become prospects for future investigation. Firstly, in this study the data are collected only from pharmaceutical organizations situated in Lahore, Pakistan; therefore, the results cannot be utilizedby other organizations. Secondly, this study was conducted in the eastern culture, specifically Pakistan, and the application of these results in other culture should be considered carefully because these findings cannot be generalized to other countries specifically western culture. To avoid common method variance, longitudinal design can be used in future investigations. Moreover, male respondents were more than female respondents which is another limitation of this study because few research studies have reported that female employees respond more positively to the managers and working relationship than males and future studies can investigate the role of gender. Future studies can employ in other industries to generalize research findings. Future studies can be conducted to explore other possible mediators or moderators to understand the relationship of managerial coaching and employee outcomes better.

This study describes the different benefits of managerial coaching and how to overcome the adverse effects of POP by effective managerial coaching. However, the current study will help to add to the empirical evidence about the understanding of the managerial coaching and facilitation of managerial coaching in different organizations. The effective managerial coaching is essential for the thriving at work, as OCB and POP make this relationship weaker. Many researchers mark managerial coaching in increasing association with active listening skills, questioning skills, logical skills, thought, quick response, openness of thoughts, numerous views in decision making, cognitive or intellectual, open communication, explanation of goals and approaches, cooperation, teamwork, and forming a supportive atmosphere (Cox et al., 2010). For enhancing thriving at work and OCB manager should provide fast response for improving performance, make opportunities for learning, and improve prospects for achievement and betterment of personnel in a coaching environment (Kim et al., 2014). Employees feel thrive in their workplace when they recognize the favors in the form of coaching affiliation with a supervisor, and subordinate feels the responsibility and commitment 
to respond by exhibiting the promising attitudes (Sonenshein et al., 2013) like OCB-I and OCB-O. To this end, negative effects of POP can be minimized by quick feedback, training, mentoring, and effective managerial coaching.

\section{References}

Abid, G. (2013). Promoting thriving at work through job characteristics for performance and absenteeism (Unpublished master's thesis). National College of Business Administration and Economics, Lahore, Pakistan.

Abid, G., Zahra, I., \& Ahmed, A. (2015). Mediated mechanism of thriving at work between perceived organization support, innovative work behavior and turnover intention. Pakistan Journal of Commerce \& Social Sciences, 9(3), 982-998.

Abid, G., \& Ahmad, A. (2016). Multifacetedness of thriving: Its cognitive, affective, and behavioral dimensions. International Journal of Information, Business, \& Management, 8(3), 121-130.

Agarwal, R., Angst, C. M., \& Magni, M. (2009). The performance impacts of coaching: A multilevel analysis using hierarchical linear modeling. International Journal of Human Resource Management, 20, 2110-2134.

Anderson, J. C., \& Gerbing, D. W. (1988). Structural equation modeling in practice: A review and recommended two-step approach. Psychological Bulletin, 103(3), 411-423.

Atinc, G., Darrat, M., Fuller, B., \& Parker, B. (2010). Perceptions of organizational politics: A meta-analysis of theoretical antecedents. Journal of Managerial Issues, 22(4), 494-513.

Bagozzi, R. P., \& Yi, Y. (1988). On the evaluation of structural equation models. Journal of the Academy of Marketing Science, 16(1), 74-94.

Baron, R. M., \& Kenny, D. A. (1986). The moderator-mediator variable distinction in social psychological research: Conceptual, strategic, and statistical considerations. Journal of Personality \& Social Psychology, 51(6), 1173-1182.

Beattie, R. S., Kim, S., Hagen, M. S., Egan, T. M., Ellinger, A. D., \& Hamlin, R. G. (2014). Managerial coaching. A review of the empirical literature and development of a model to guide future practice. Advances in Developing Human Resources, 16(2), 184-201.

Bester, J., Stander, M. W., \& Van Zyl, L. E. (2015). Leadership empowering behavior, psychological empowerment, organizational citizenship behaviors and turnover intention in a manufacturing division. SA Journal of Industrial Psychology, 41(1), 1-14.

Blau, P. (1964). Exchange and power in social life. New York: Wiley.

Boyatzis, R. E., Smith, M. L., \& Beveridge, A. J. (2012). Coaching with compassion: Inspiring health, well-being, and development in organizations. The Journal of Applied Behavioral Science, 49(2), 153-178.

Brislin, R. W. (1980). Translation and content analysis of oral and written material. In H. C. Triandis \& J. W. Berry (Eds.), Handbook of cross-culture psychology (pp. 389-444). Boston,MA: Allyn \& Bacon.

Browne, M. W., \&Cudeck, R. (1993). Alternative Ways of Assessing Model Fit. In K. A. Bollen, \&J. S. Long (Eds.), Testing Structural Equation Models (pp. 136-162). Newbury Park, CA Sage Focus Editions.

Butt, M. R., Imran, A., Shah, F. T., \& Jabbar, A. (2013). Perception of organizational politics and job outcomes in a publicsector organization: The moderating role of teamwork. Middle-East Journal of Scientific Research, 18(9), 1268-1276.

Chang, C. H., Rosen, C. C., \& Levy, P. E. (2009). The relationship between perceptions of organizational politics and employee attitudes, strain, and behavior: A meta-analytic examination. Academy of Management Journal, 52(4), $779-801$.

Cheung, G. W., \& Rensvold, R. B. (2002). Evaluating goodness-of-fit indexes for testing measurement invariance. Structural Equation Modeling, 9(2), 233-255.

Cohen, E., \& Tichy, N. (1998). Teaching: the heart of leadership. In the Healthcare Forum Journal, 41(2), 20-30.

Colquitt, J. A., Scott, B. A., \& LePine, J. A. (2007). Trust, trustworthiness, and trust propensity: A meta-analytic test of their unique relationships with risk taking and job performance. Journal of Applied Psychology, 92(4), 909-927.

Cox, E., Bachkirova, T., \& Clutterbuck, D. (2010). The complete handbook of coaching. London, England: Sage.

Dahling, J. J., Taylor, S. R., Chau, S. L., \& Dwight, S. A. (2016). Does coaching matter? a multilevel model linking managerial coaching skill and frequency to sales goal attainment. Personnel Psychology, 69(4), 863-894.

Deci, E. L., \& Ryan, R. M. (1985). Intrinsic motivation and self-determination in human behavior. New York, NY: Plenum Press. 
Deeter-Schmelz, D. R., Goebel, D. J., \& Kennedy, K. N. (2008). What are the characteristics of an effective sales manager? An exploratory study comparing salesperson and sales manager perspectives. Journal of Personal Selling \& Sales Management, 28(1), 7-20.

Delery, J. E., \& Roumpi, D. (2017). Strategic human resource management, human capital, and competitive advantage: Is the field going in circles? Human Resource Management Journal, 27(1), 1-21.

Dekas, K. H., Bauer, T. N., Welle, B., Kurkoski, J., \& Sullivan, S. (2013). Organizational citizenship behavior, version 2.0: A review and qualitative investigation of OCBs for knowledge workers at Google and beyond. The Academy of Management Perspectives, 27(3), 219-237.

Dhar, R. L. (2009). Living with organizational politics: an exploration of employee's behavior. International Journal of Management \& Innovation, 1(1), 37-56.

Eisenberger, R., Fasolo, P., \& Davis-LaMastro, V. (1990). Perceived organizational support and employee diligence, commitment, and innovation. Journal of Applied Psychology, 75(1), 51-59.

Ellinger, A. D., Ellinger, A. E., Hamlin, R. G., \& Beattie, R. S. (2010). Achieving improved performance through managerial coaching. In R. Watkins \& D. Leigh (Eds.), Handbook of improving performance in the workplace, Volume 2: Selecting and implementing performance interventions (pp. 275-298). San Francisco, CA: Pfeiffer/International Society for Performance Improvement.

Ellinger, A. D., Ellinger, A. E., \& Keller, S. B. (2003). Supervisory coaching behavior, employee satisfaction, and warehouse employee performance: A dyadic perspective in the distribution industry. Human Resource Development Quarterly, 14(4), 435-458.

Ellinger, A. D., \& Kim, S. (2014). Coaching and human resource development examining relevant theories, coaching genres, and scales to advance research and practice. Advances in Developing Human Resources, 16, 127-138.

Ellinger, A. D., \& Cseh, M. (2007). Contextual factors influencing the facilitation of others' learning through everyday work experiences. Journal of Workplace Learning, 19(7), 435-452.

Elliott, E. S., \& Dweck, C. S. (1988). Goals: an approach to motivation and achievement. Journal of Personality \& Social Psychology, 54(1), 5-12.

Erkutlu, H., \& Chafra, J. (2015). Empowering leadership and organizational job embeddedness: The moderating roles of task interdependence and organizational politics. Procedia-Social \& Behavioral Sciences, 210, 3-10.

Ferris, G. R., \& Kacmar, K. M. (1992). Perceptions of organizational politics. Journal of management, 18(1), 93-116.

Ferris, G. R., Russ, G. S., \& Fandt, P. M. (1989). Politics in organizations. Impression Management in the Organization, 143(170), 79-100.

Fornell, C., \& Larcker, D. F. (1981). Evaluating structural equation models with unobservable variables and measurement error. Journal of Marketing Research, 39-50.

Gadot, E. V. (2007). Leadership style, organizational politics, and employees' performance: An empirical examination of two competing models. Personnel Review, 36(5), 661-683.

Gilley, A., Gilley, J. W., \& Kouider, E. (2010). Characteristics of managerial coaching. Performance Improvement Quarterly, 23(1), 53-70.

Grant, A. M. (2006). Workplace and executive coaching: A bibliography from the scholarlybusiness literature. In R. Stober \& A. M. Grant (Eds.), Evidence based coaching handbook:Putting best practices to work for your clients (pp. 367-398). Hoboken, NJ: Wiley.

Hagen, M. S. (2010). Black belt coaching and project outcomes: An empirical investigation. Quality Management Journal, 17(2), 54-67.

Hahn, H. J. (2016). The effects of managerial coaching on work performance: The mediating roles of role clarity and psychological empowerment (Unpublished Doctoral dissertation). University of Minnesota.

Hair Jr, J. F., Anderson, R. E., Tatham, R. L., \&Black, W. C. (1995). Multivariate data analysis with readings. New Jersy: Prentice Hall.

Hall, A. T., Hochwarter, W. A., Ferris, G. R., \& Bowen, M. G. (2004). The dark side of politics in organizations. In R. W. Griffin \& A. M. O'Leary-Kelly (Eds.), The dark side of organizational behavior (pp. 237-261). San Francisco: Jossey-Bass.

Hu, L. T., \& Bentler, P. M. (1999). Cutoff criteria for fit indexes in covariance structure analysis: Conventional criteria versus new alternatives. Structural equation modeling: A Multidisciplinary Journal, 6(1), 1-55. 
Huang, J. T., \& Hsieh, H. H. (2015). Supervisors as good coaches: Influences of coaching on employees' in-role behaviors and proactive career behaviors. The International Journal of Human Resource Management, 26(1), 42-58.

Iacobucci, D., Saldanha, N., \& Deng, X. (2007). A meditation on mediation: Evidence that structural equations models perform better than regressions. Journal of Consumer Psychology, 17(2), 139-153.

Jaques, E. (2017). Requisite organization: A total system for effective managerial organization and managerial leadership for the $21^{\text {st }}$ century. Routledge.

Jones, R. J., Woods, S. A., \& Guillaume, Y. R. (2016). The effectiveness of workplace coaching: A meta-analysis of learning and performance outcomes from coaching. Journal of Occupational \& Organizational Psychology, 89(2), 249-277.

Kacmar, K. M., \& Carlson, D. S. (1997). Further validation of the perceptions of politics scale (POPS): A multiple sample investigation. Journal of Management, 23(5), 627-658.

Kacmar, K. M., \& Baron, R. A. (1999). Organizational politics: The state of the field, links to related processes, and an agenda for future research. Research in Personnel \& Human Resources Management, 17, 1-39.

Kahn, W. A. (1990). Psychological conditions of personal engagement and disengagement at work. Academy of Management Journal, 33(4), 692-724.

Kim, S. (2010). Managerial coaching behavior and employee outcomes: A structural equation modeling analysis (Unpublished doctoral dissertation). Texas A\&M University, College Station.

Kim, S. (2014). Assessing the influence of managerial coaching on employee outcomes. Human Resource Development Quarterly, 25(1), 59-85.

Kim, S., Egan, T. M., Kim, W., \& Kim, J. (2013). The impact of managerial coaching behavior on employee work-related reactions. Journal of Business \& Psychology, 28(3), 315-330.

Kim, S., Egan, T. M., \& Moon, M. J. (2014). Managerial coaching efficacy, work-related attitudes, and performance in public organizations: A comparative international study. Review of Public Personnel Administration, 34, 237-262.

Kim, S., \& Kuo, M. H. (2015). Examining the relationships among coaching, trustworthiness, and role behaviors a social exchange perspective. The Journal of Applied Behavioral Science, 51(2), 152-176.

Kim, J. J., Eom, T. K., Kim, S. W., \& Youn, M. K. (2015). Effects of ethical management on job satisfaction and turnover in the South Korean service industry. International Journal of Industrial Distribution \& Business, 6(1), 17-26.

Kline, R. B. (2005). Principles and practice of structural equation modeling. New York: Guilford.

Kottke, J. L., \& Sharafinski, C. E. (1988). Measuring perceived supervisory and organizational support. Educational \& Psychological Measurement, 48(4), 1075-1079.

Kwon, K. M. (2015). A Study on airlines employee's coaching leadership, service attitude, and innovation behavior- focusing on moderation effects from job autonomy. Journal of the Aviation Management Society of Korea, 13(1), 105-126.

Lambert, M., Vero, J. \& B. Zimmermann. (2012). Vocational training and professional development: A capability perspective. International Journal of Training \& Development, 16(3), 164-182.

Lau, P. Y. Y., Tong, J. L. T., Lien, B. Y. H., Hsu, Y. C., \& Chong, C. L. (2017). Ethical work climate, employee commitment and proactive customer service performance: Test of the mediating effects of organizational politics. Journal of Retailing \& Consumer Services, 35, 20-26.

Liu, X., \& Batt, R. (2010). How supervisors influence performance: A multilevel study of coaching and group management in technology-mediated services. Personnel Psychology, 63(2), 265-298.

Liang, T., \& Wang, Y. (2016). Organizational Silence in State-Owned Enterprises: Intermediary Role of the Perceptions of Organizational Politics. American Journal of Industrial \& Business Management, 6(5), 640-655.

Mattila, A. S., \& Enz, C. A. (2002). The role of emotions in service encounters. Journal of Service Research, 4(4), $268-277$.

May, D. R., Gilson, R. L., \& Harter, L. M. (2004). The psychological conditions of meaningfulness, safety and availability and the engagement of the human spirit at work. Journal of Occupational \& Organizational Psychology, 77(1), 11-37.

McGill, M. E., \& Slocum, J. W. (1999). A little leadership, please? Organizational Dynamics, 26(3), 39-49.

Motowidlo, S. J., \& Van Scotter, J. R. (1994). Evidence that task performance should be distinguished from contextual performance. Journal of Applied Psychology, 79(4), 475-480. 
Muhlberger, M. D., \& Traut-Mattausch, E. (2015). Leading to effectiveness: Comparing dyadic coaching and group coaching. The Journal of Applied Behavioral Science, 51(2), 198-230.

Nix, G., Ryan, R. M., Manly, J. B., \& Deci, E. L. (1999). Revitalization through self-regulation: The effects of autonomous and controlled motivation on happiness and vitality. Journal of Experimental Social Psychology, 35, 266-284.

Oh, H. S., \& Tak, J. K. (2016). Managerial coaching effect on organizational effectiveness: Mediating roles of psychological ownership and learning goal orientation. Journal of Distribution Science, 14, 5-16.

Organ, D. W., Podsakoff, P. M., \& MacKenzie, S. B. (2005). Organizational citizenship behavior: Its nature, antecedents, and consequences. Thousand Oakes: Sage Publications.

Park, S. (2007). Relationships among managerial coaching in organizations and the outcomesof personal learning, organizational commitment, and turnover intention (Unpublisheddoctoral dissertation). University of Minnesota, Minneapolis.

Peterson, D. B., \& Hicks, M. D. (1996). Leader as coach: Strategies for coaching and developing others. Minneapolis, MN: Personnel Decisions International.

Podsakoff, P. M., MacKenzie, S. B., Lee, J. Y., \& Podsakoff, N. P. (2003). Common method biases in behavioral research: A critical review of the literature and recommended remedies. Journal of Applied Psychology, 88(5), 879-903.

Podsakoff, P. M., MacKenzie, S. B., Moorman, R. H., \& Fetter, R. (1990). Transformational leader behaviors and their effects on followers' trust in leader, satisfaction, and organizational citizenship behaviors. The Leadership Quarterly, 1(2), 107142 .

Pousa, C., \& Mathieu, A. (2010). Sales managers' motivation to coach salespeople: An exploration using expectancy theory. International Journal of Evidence Based Coaching \& Mentoring, 8(1), 34-51.

Pousa, C., \& Mathieu, A. (2015). Is managerial coaching a source of competitive advantage? Promoting employee selfregulation through coaching. Coaching: An International Journal of Theory, Research \& Practice, 8(1), 20-35.

Pousa, C., Mathieu, A., \& Trepanier, C. (2017). Managing salesperson performance through coaching: The moderating role of selling experience. In Marketing at the Confluence between Entertainment and Analytics (pp. 653-657). Springer, Cham.

Porath, C., Spreitzer, G., Gibson, C., \& Garnett, F. G. (2012). Thriving at work: Toward its measurement, construct validation, and theoretical refinement. Journal of Organizational Behavior, 33(2), 250-275.

Poon, J. M. (2003). Situational antecedents and outcomes of organizational politics perceptions. Journal of Managerial Psychology, 18(2), 138-155.

Ram, P., \& Prabhakar, G. V. (2010). Leadership styles and perceived organizational politics as predictors of work related outcomes. European Journal of Social Sciences, 15(1), 40-55.

Ratiu, L., David, O. A., \& Baban, A. (2017). Developing managerial skills through coaching: Efficacy of a cognitivebehavioral coaching program. Journal of Rational-Emotive \& Cognitive-Behavior Therapy, 35(1), 88-110.

Rodell, J. B., \& Judge, T. A. (2009). Can "good" stressors spark "bad" behaviors? The mediating role of emotions in links of challenge and hindrance stressors with citizenship and counterproductive behaviors. Journal of Applied Psychology, 94(6),1438-1451.

Rusbult, C., Campbell, M., \& Price, M. (1990). Rational selective exploitation and distress: Employee reactions to performance based and mobility-based reward allocations. Journal of Personality \& Social Psychology, 59(3), 487-500.

Ryan, R. M., \& Deci, E. L. (2000). Self-determination theory and the facilitation of intrinsic motivation, social development, and well-being. American Psychologist, 55(1),68-78.

Saleem, H. (2015). The impact of leadership styles on job satisfaction and mediating role of perceived organizational politics. Procedia-Social \& Behavioral Sciences, 172, 563-569.

Sonenshein, S., Dutton, J. E., Grant, A. M., Spreitzer, G. M., \& Sutcliffe, K. M. (2013). Growing at work: Employees' interpretations of progressive self-change in organizations. Organization Science, 24(2), 552-570.

Spreitzer, G., Sutcliffe, K., Dutton, J., Sonenshein, S., \& Grant, A. M. (2005). A socially embedded model of thriving at work. Organization Science, 16(5), 537-549.

Spreitzer, G. M., \& Porath, C. L. (2014). Self-determination theoryas a nutrimentforthriving: Buildingan integrative modelofhuman growth at work. In M. Gagné, (Eds.), Oxford handbook of work engagement, motivation and selfdetermination theory (pp. 245-258). New York, NY: Oxford University Press.

Spreitzer, G., Porath, C. L., \& Gibson, C. B. (2012). Toward human sustainability: How to enable more thriving at work. Organizational Dynamics, 41(2), 155-162. 
Tabachnick, B. G., \& Fidell, L. S. (1996). Using multivariate statistics. New York, NY: HarperCollins.

Turner, C., \& McCarthy, G. (2015). Coachable moments: Identifying factors that influence managers to take advantage of coachable moments in day-to-day management. International Journal of Evidence Based Coaching and Mentoring, 13(1), $1-13$.

Valle, M., \& Perrewe, P. L. (2000). Do politics perceptions relate to political behaviors? Tests of an implicit assumption and expanded model. Human relations, 53(3), 359-386.

Van Dyne, L., Cummings, L. L., \& Parks, J. M. (1995). Extra-role behaviors: In pursuit of construct and definitional clarity (A bridge over muddied waters). In L. L. Cummings \& B. M. Staw (Eds.), Research in organizational behavior (pp. 215-285). Greenwich, CT: JAI Press.

Vigoda, E. (2000). Organizational politics, job attitudes, and work outcomes: Exploration and implications for the public sector. Journal of Vocational Behavior, 57(3), 326-347.

Vigoda, E. (2002). Stress-related aftermaths to workplace politics: The relationships among politics, job distress and aggressive behavior in organizations. Journal of Organizational Behavior, 23(5),571-591.

Wiesenfeld, B. M., Raghuram, S., \& Garud, R. (2001). Organizational identification among virtual workers: The role of need for affiliation and perceived work-based social support. Journal of Management, 27(2), 213-229.

Williams, L. J., \& Anderson, S. E. (1991). Job satisfaction and organizational commitment as predictors of organizational citizenship and in-role behaviors. Journal of Management, 17(3), 601-617.

Woo, H. R. (2017). Exploratory study examining the joint impacts of mentoring and managerial coaching on organizational commitment. Sustainability, 9(2), 181-196.

Yang, H. C., Cho, H. Y., Kim, J. J., Eom, T. K., Kim, S. W., \& Youn, M. K. (2015). Effects of individuals, leader relationships, and groups on innovative work behaviors. International Journal of Industrial Distribution \& Business, 6(3), 19-25.

Ye, R., Wang, X. H., Wendt, J. H., Wu, J., \& Euwema, M. C. (2016). Gender and managerial coaching across cultures: Female managers are coaching more. The International Journal of Human Resource Management, 27(16), 1791-1812.

Zagenczyk, T. J., Scott, K. D., Gibney, R., Murrell, A. J., \& Thatcher, J. B. (2010). Social influence and perceived organizational support: A social networks analysis. Organizational Behavior \& Human Decision Processes, 111(2), 127138.

Zemke, R. (1996). The corporate coach. Training, 33(12), 24-28.

Zhang, A. Y., Tsui, A. S., Song, L. J., Li, C., \& Jia, L. (2008). How do I trust thee? The employee-organization relationship, supervisory support, and middle manager trust in the organization. Human Resource Management, 47(1), 111-132. 